Innovation and the State 



\section{Innovation and the State}

Political Choice and Strategies for

Growth in Israel, Taiwan,

and Ireland

Dan Breznitz

Yale University Press

New Haven and London 
Copyright (C) 2007 by Dan Breznitz.

All rights reserved.

This book may not be reproduced, in whole or in part, including illustrations, in any form (beyond that copying permitted by Sections I07 and I08 of the U.S. Copyright Law and except by reviewers for the public press), without written permission from the publishers. The paper in this book meets the guidelines for permanence and durability of the Committee on Production Guidelines for Book Longevity of the Council on Library Resources.

Set in Adobe Garamond by Binghamton Valley Composition

Printed in the United States of America.

Library of Congress Cataloging-in-Publication Data

Breznitz, Dan.

Innovations and the state : political choice and strategies for growth in Israel, Taiwan, and Ireland / Dan Breznitz.

p. $\mathrm{cm}$.

Includes bibliographical references and index.

ISBN 978-0-300-I20I8-9 (cloth : alk. paper) I. Information technologyIsrael. 2. Information technology-Taiwan. 3. Information technologyIreland. 4. Israel-Economic policy. 5. Taiwan-Economic policy.

6. Ireland-Economic policy. I. Title.

$\mathrm{HC}_{415.25 . Z 9 I 553 \quad 2007}$

$338.9-\mathrm{dc} 22$

$$
2006038733
$$

A catalogue record for this book is available from the British Library.

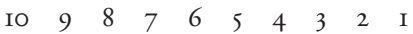


To my loving mother Tamar and my beloved wife Shiri, the two women who make my life a joy 
